\title{
Causes of construction accidents in Oman
}

\section{Tariq Umar*}

School of Built Environment and Architecture, London South Bank University, London, SE1 0AA, UK

and

College of Engineering, A'Sharqiyah University, Ibra, 400, Oman

Email: tariqumar1984@gmail.com

${ }^{\star}$ Corresponding author

\section{Charles Egbu}

School of Built Environment and Architecture, London South Bank University, London, SE1 0AA, UK

Email: egbuc@lsbu.ac.uk

\begin{abstract}
Considering the costs associated with accidents in construction, a model identifying root causes of accidents is proposed for construction organisations in Oman. The model classifies the accidents in construction mainly arising from main four causes: 'equipment/materials', 'workers', 'environment' and 'management'. The model is applied to a road construction project in Oman to trace the root causes of accidents. It can also be applied to construction projects in other sectors such as building or process plant construction. Further research is recommended to extend the study to other projects in the construction sector in order to generalise the findings. Although the frequency distribution of accidents is likely to vary from project to project, understanding the underlying pattern of their causes helps to pinpoint the key areas where resources should be directed in the organisations' efforts to deliver the goal of zero accidents.
\end{abstract}

Keywords: health and safety; management; construction hazards; accidents; workers; materials and equipment; environment; highway project; cost of accidents; types of construction accidents; inspections; project management.

Reference to this paper should be made as follows: Umar, T. and Egbu, C. (2018) 'Causes of construction accidents in Oman', Middle East J. Management, Vol. 5, No. 1, pp.21-33.

Biographical notes: Tariq Umar has completed a Master degree in Civil Engineering and registered as a Chartered Civil Engineer with Engineering Council UK. He is pursuing his $\mathrm{PhD}$ in Construction Management from London South Bank University. He has more than nine years academic research and teaching experience and has published several research articles in the area of construction management, renewable energy and materials. 
He has serve in the civil engineering industry for four years. He is based in Oman since 2012 and working as Lecturer in Civil Engineering at A'Sharqiyah University. He is an approved mentor of the Institution of Civil Engineers (UK).

Before coming to LSBU, Charles Egbu held the Chair in Project Management and Strategic Management in Construction and was Head of Built Environment at the University of Salford in Manchester - where he has worked for 16 years. He holds numerous Fellowships with professional bodies and has contributed to more than 350 publications including 10 books, the most recent being "Knowledge Capture in Small and Medium Enterprise". He has to date obtained research and enterprise income in excess of $£ 25 \mathrm{~m}$ and brings extensive experience in these areas as well as a strong international dimension.

\section{Introduction}

Worldwide occupational injury rates in the construction sector are high compared with all other major industries (Lehtola et al., 2008). Unlike other industries such as manufacturing, construction is composed of a transient workforce (Dubois and Gadde, 2002; Kadefors, 1995), where project personnel from different cultures and backgrounds are expected to work together in a constantly changing work organisation and structure. Construction is always risky due to outdoor operations, work at height, complicated on-site plant machinery and equipment operations coupled with the worker's attitudes and behaviours towards safety (Choudhry et al., 2007). Statistics published by the International Labor Organization in 2016 indicate that at least 108,000 workers are killed on construction sites every year, a figure that represents about $30 \%$ of all fatal occupational injuries. Data from a number of industrialised countries show that construction workers are three to four times more likely than other workers to die from accidents at work. In the developing world, the risks associated with construction work may be three to six times higher. Accidents include not only direct physical injury to persons or damage to property, but also short and long term effects or incidents due to other exposures on sites that affect the workers' health and physical well-being. The costs of accidents (direct and indirect) can be substantial. The costs of accidents in the USA were determined as $6.5 \%$ of the total value of completed work and in the UK it is approximately $8.5 \%$ of the tender value (BRT, 1995; Anderson, 1997). Research conducted in the UK on cost and benefit analysis revealed that when total costs of accident prevention were compared to the total benefits of accident prevention, the benefits far outweigh the costs of accident prevention by a ratio of approximately $3: 1$, which means that when contractors, irrespective of their sizes, spend $£ 1.00$ on accident prevention, they gain $£ 3.00$ (Ikpe et al., 2012). The cost of accidents can be understood by contractors and represents a tangible measure that can be related to project financial accounts and both the income statement and balance sheet of a contractor (Tang et al., 2004; Booth and Panopoulos, 2005). The costs of accident also affect the workers and society, as illustrated in Table 1. Thus, this category of cost is very often at the forefront of considerations of the costs of health and safety.

Construction is a major industry providing jobs to millions of people and contributing to countries and the world economy. Contribution towards the Omani economy is around 
$10 \%$ of the total gross domestic product (GDP) and employs $18 \%$ of the total population (NCSI, 2015). Oman labour law empowers the ministry of manpower to ensure the health and safety standards through ministry inspectors and in event of the existence of any danger which threatens the safety and health of the workers, the Ministry can take necessary measures to close down the place of work wholly or partially, or to stop the operation of one or more machinery until the elimination of the causes of such danger. The ministry could improve further the process of inspections and penalties by benchmarking its system with Occupational Safety and Health Administration (OSHA) (USA) and health, safety and environment (HSE) (UK).

Table 1 Costs of accidents incurred by stakeholders

\begin{tabular}{|c|c|c|}
\hline Stakeholders & Intangible costs & Tangible costs \\
\hline Worker & $\begin{array}{l}\text { Pain and suffering, moral and } \\
\text { psychological suffering } \\
\text { (especially in the case of death } \\
\text { and permanent disability) }\end{array}$ & $\begin{array}{l}\text { Loss of salary, reduction of professional } \\
\text { capacity, loss of time (medical } \\
\text { treatment), site compliance of health, } \\
\text { and safety issues }\end{array}$ \\
\hline $\begin{array}{l}\text { Family and friends of } \\
\text { the affected worker }\end{array}$ & $\begin{array}{l}\text { Moral and psychological } \\
\text { suffering, medical and family } \\
\text { burden }\end{array}$ & $\begin{array}{l}\text { Financial loss, extra costs, loss of time } \\
\text { to take care of the injured worker }\end{array}$ \\
\hline Coworkers & $\begin{array}{l}\text { Bad feeling, worry, or panic } \\
\text { (in case of serious or frequent } \\
\text { accidents) }\end{array}$ & $\begin{array}{l}\text { Loss of time, increase of workload, and } \\
\text { training of temporary staff }\end{array}$ \\
\hline Employer & $\begin{array}{l}\text { Bad reputation, litigation cost, } \\
\text { insurance cost, and } \\
\text { compensation cost }\end{array}$ & $\begin{array}{l}\text { Decrease in production; damages to } \\
\text { machinery, equipment, and material; } \\
\text { quality losses; recruitment and training } \\
\text { of new staff; increase of production } \\
\text { costs; increase of insurance premium; } \\
\text { administrative costs; litigation costs; } \\
\text { and absenteeism }\end{array}$ \\
\hline Society & $\begin{array}{l}\text { Reduction of the human labour } \\
\text { potential, and reduction of the } \\
\text { quality of life }\end{array}$ & $\begin{array}{l}\text { Loss of production, increase of social } \\
\text { costs, medical treatment and } \\
\text { rehabilitation costs, and decrease of } \\
\text { standard of living }\end{array}$ \\
\hline
\end{tabular}

Source: Ikpe et al. (2012)

Knowing the root causes of accidents can help construction organisations in preventing accidents in future through appropriate risk mitigation measures and by addressing the weak areas associated with accidents. This paper develops a model for identifying the root causes of accidents in construction. The root causes of accidents are broadly divided into four categories: equipment/materials, workers, environment and management. The model described in this paper will help construction organisations in Oman to identify the root causes of accidents which will further help the construction organisations in developing strategies to reduce accidents on construction sites.

\section{Literature review}

Construction researchers have proposed several accident causation models and root causes. McClay's (1989) 'universal framework' identified three key elements of 
accidents: hazards, human actions, and functional limitations. Hinze's (1996) distraction theory argued that production pressures can distract workers from the hazards and increase the probability of accidents. Abdelhamid and Everett (2000) identified management deficiencies, training, and workers' attitude as the three general root causes. The 'constraints-response' model by Suraji et al. (2001) argues that project conditions or management decisions can cause responses that create inappropriate conditions or actions that lead to accidents. Gibb et al. (2006) identified worker, workplace, material and equipment as shaping factors of accidents in construction. The accident root causes tracing model (ARCTM) presented by Abdelhamid and Everett (2000) discussed four main causes of accidents that are from:

- management actions/inactions

- unsafe acts of worker or coworker

- non-human related events

- an unsafe condition that is a natural part of initial construction site conditions.

The model proposed by Mitropoulos et al. (2005) identifies the need for two accident prevention strategies

- reliable production planning to reduce task unpredictability

- error management to increase the workers' ability to avoid, trap, and mitigate errors.

A study into the causes of accidents in the construction industry in Uganda linked the major causes of accidents in construction to inadequate supervision, use of incompetent personnel and use of inappropriate construction techniques (Lubega et al., 2000). The research concluded that accidents are caused by a wide range of factors including:

- lack of awareness of safety regulations

- lack of enforcement of safety regulations

- poor regard for safety by people involved in construction projects

- engaging incompetent personnel

- non-vibrant professionalism

- mechanical failure of construction machinery/equipment

- physical and emotional stress

- chemical impairment.

Research conducted by Hamid et al. (2008) in Malaysia on the causes of accidents on construction sites concludes that the main cause of construction accidents are workers' negligence, failure of workers to obey work procedures, work at high elevation, operating equipment without safety devices, poor site management, harsh work conditions, low knowledge and skill level of workers, failure to use personal protective equipment and poor workers attitude about safety. 
Haslam et al. (2005) in their studies of 100 individual construction accidents summarised the levels of involvement of key factors in the accidents as: problems arising from workers or the work team (70\% of accidents), workplace issues $(49 \%)$, shortcomings with equipment-including personal protective equipment (PPE) $(56 \%)$, problems with suitability and condition of materials $(27 \%)$, and deficiencies with risk management (84\%). They further suggest that design and cultural factors shape the circumstances found in the work place, giving rise to the acts and conditions which, in turn, lead to accidents. It is argued that attention to the originating influences will be necessary for sustained improvements in construction safety to be achieved.

Research on the causes and effects of accidents on construction sites conducted Nigeria found that workers are the major contributors to the causes of accidents on construction sites, which ranges from $53 \%$ to $67 \%$ of the main causes of accidents in different sizes of construction organisation. Although there are further 25 different factors which contribute to accidents on construction sites, the research also concludes that workers are the most affected people from accidents whatever the cause (Kadiri et al., 2014).

The study by Ali et al. (2010) reveals that accidents are generally caused by unsafe acts and unsafe conditions besides other sub-causes. Accidents can result from a combination of contributory causes. The main causes of construction accidents identified in their study are the human element, poor site management, failure to use personal protective equipment and unsafe equipment used in construction work.

On the basis of the above literature review the proposed model for tracing the root causes of accidents discussed in this paper classify the accidents arising from four main causes that can be related to:

- equipment/materials

- worker

- environment

- management.

\section{Research methodology}

The main research question in this research is to identify the main causes of accidents in construction in Oman. The methodology adopted in this research includes the collection of actual accidents data from a construction organisation that just completed a major highway project. Five main construction organisations that were involved in delivering the project were asked for cooperation to investigate the root causes of accident on the project. These organisations were informed about the purpose of the research and the information required for the purpose of the research. Only one construction organisation agreed to cooperate on the condition that the name of the organisation would not be revealed. This construction organisation was carrying out a $75 \mathrm{~km}$ road construction project estimated to cost of US\$ 305.90 million. The project was started in September 2011 and $82 \%$ of the work was completed in April 2016. The accidents data was collected directly from the project H\&S team and included following information: 
- type, nature and location of accident

- statement of workers involved in the incident

- report of the safety or site supervisor

- photos of the accidents

- medical reports in case of medical injury.

A total of 623 accidents data was provided by the H\&S team. These accidents were of different types in nature. Based on the accident data, the different types of accidents were initially classified based on their nature under.

\subsection{Alternate work injury (AWI)}

A work injury that results in the injured person being able to perform only restricted (light) duties in the original workplace on the first scheduled work day or shift (or any subsequent work day or shift) on the day after the incident.

\subsection{First aid injury (FAI)}

A work injury that requires first aid treatment, including observations, tetanus toxoid (TT) injections, non-prescription drugs, pain killers, examination, X-rays, oral rehydration, minor dressings even if carried out in the hospital.

\subsection{Loss time injury (LTI)}

A work injury or disease resulting in a fatality, permanent disability or time lost from work of one or more complete work days or shifts, following the fourth day or shift of the incident. Fatalities causes from suicide or natural causes are excluded.

\subsection{Medical treatment injury (MTI)}

A work injury that requires treatment other than first aid at a hospital or other medical facility.

\subsection{Property/equipment damage}

These are incidents resulting from workplace activities that caused damage to property or equipment only.

To find the root causes of these incidents a model was developed to identify the causes of accidents and to relate them to the main causes from material/equipment, workers, environment and management as shown in Table 2. These main causes of accidents were identified from a literature review on different models of the root causes of accidents in construction.

The process used in this research to identifying the root causes of accidents in construction is explained in Figure 1. 
Table 2 Model for tracing roots causes of accidents

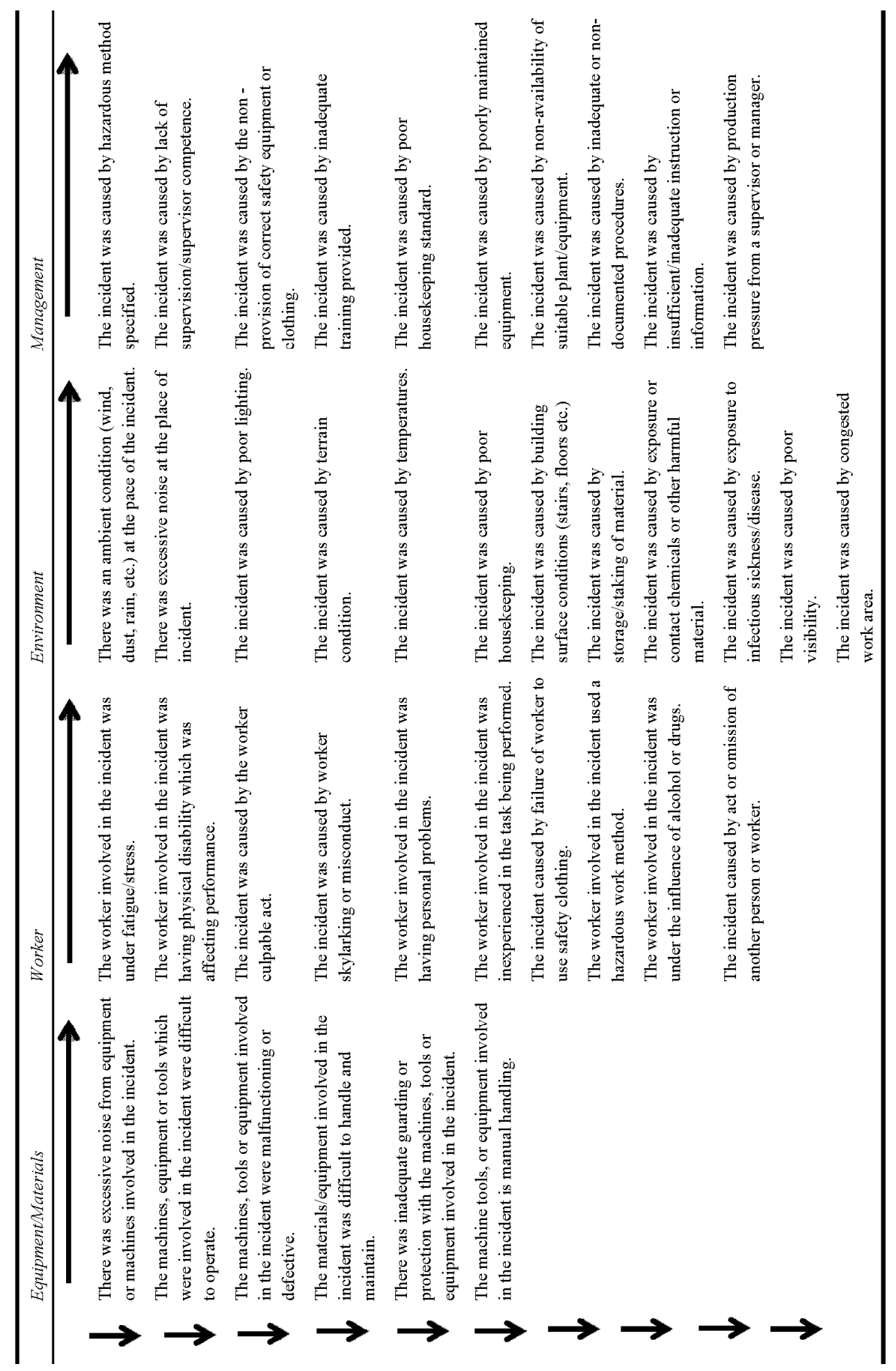


Figure 1 Process to identify root causes of accidents (see online version for colours)

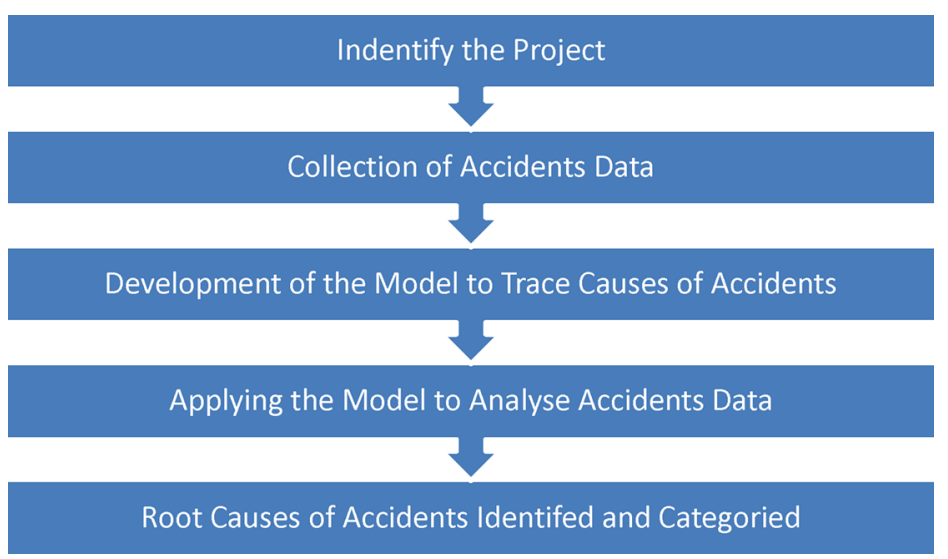

\section{Number of accidents in selected project}

The record maintained by the project HSE team shows that there were a total of 623 accidents from September 2011 to April 2016 as shown in Table 3. Property/equipment damage accidents were at the top with a total number of 580 accidents, followed by MTI (15), FAI (14), LTI (9) and AWI (5). The average numbers of workers on the project during this period (September 2011-April 2016) were 2000.

Table 3 Summary of different types of accidents (September 2011-April 2016)

\begin{tabular}{lcccccc}
\hline Year & $\begin{array}{c}\text { Property/ } \\
\text { equipment } \\
\text { damage }\end{array}$ & $\begin{array}{c}\text { Alternate work } \\
\text { injury }(\text { AWI })\end{array}$ & $\begin{array}{c}\text { First aid } \\
\text { injury }(\text { FAI })\end{array}$ & $\begin{array}{c}\text { Loss time } \\
\text { injury }(\text { LTI })\end{array}$ & $\begin{array}{c}\text { Medical } \\
\text { treatment injury } \\
(\text { MTI })\end{array}$ & Total \\
\hline 2011 & 0 & 0 & 0 & 0 & 0 & 0 \\
2012 & 7 & 1 & 1 & 0 & 2 & 11 \\
2013 & 155 & 0 & 3 & 3 & 4 & 165 \\
2014 & 164 & 2 & 0 & 5 & 5 & 176 \\
2015 & 179 & 2 & 7 & 1 & 4 & 193 \\
2016 & 75 & 0 & 3 & 0 & 0 & 78 \\
Total & 580 & 5 & 14 & 9 & 15 & 623 \\
\hline
\end{tabular}

Considering the importance of inspection in ensuring proper health and safety at the workplace, the project HSE team was requested to provide a record of all internal and external inspections carried out during the project period. The ultimate purpose of the enforcing authorities is to ensure that duty holders manage and control risks effectively, thus preventing harm. The term 'enforcement' has a wide meaning and applies to all dealings between enforcing authorities and those on whom the law places duties (employers, the self-employed, employees and others). The purpose of enforcement is to: 
- $\quad$ ensure that duty holders take action to deal immediately with serious risks

- $\quad$ promote and achieve sustained compliance with the law

- $\quad$ ensure that duty holders who breach health and safety requirements, and directors or managers, who fail in their responsibilities, may be held to account.

The inspection record shows that there were a total of 2392 HSE inspections carried out during the project period (September 2011-April 2016). The number of internal inspections conducted by the project HSE team consists of one HSE advisor and five HSE officers were 2376. The contractor head office HSE team conducted a total of 12 inspections. There were four inspections conducted by different government agencies out of which two were carried out by Civil Defence authority in 2013, One by Ministry of Manpower in 2014 and the last one was by Ministry of Environment and Climate Affairs in 2015. Table 4 shows the record of HSE internal and external inspections conducted from 2011 to 2016 on this particular project.

Table 4 Summary of internal and external HSE inspections on the project (September 2011-April 2016)

\begin{tabular}{ccccc}
\hline Year & $\begin{array}{c}\text { Internal inspections } \\
\text { by project HSE team }\end{array}$ & $\begin{array}{c}\text { External inspections by } \\
\text { contractor head office HSE team }\end{array}$ & $\begin{array}{c}\text { External inspections by } \\
\text { government authorities }\end{array}$ & Total \\
\hline 2011 & 0 & 0 & 0 & 0 \\
2012 & 461 & 4 & 0 & 465 \\
2013 & 791 & 2 & 2 & 795 \\
2014 & 535 & 3 & 1 & 539 \\
2015 & 406 & 3 & 1 & 410 \\
2016 & 183 & 0 & 0 & 183 \\
Total & 2376 & 12 & 4 & 2392 \\
\hline
\end{tabular}

\section{$5 \quad$ Analysis and discussion}

The HSE policy of the construction organisation define the procedure for incident reporting, which requires the workplace manager and HSE in-charge to determine whether a specific incident requires further investigation or not. The process of reporting an incident by the workplace manager and HSE in-charge include collection of necessary information to determine what happened, where and who was involved. To understand the causes of different accidents that occurred on the project, the project team was requested to provide the incident investigation reports for detailed analysis and study. A total of 44 different incident reports were provided by the HSE team of the project. These reports were initially assessed against the model developed for tracing the root causes of accidents. It was found that only 22 reports had sufficient information to be used for tracing the root causes. Thus the valid accidents data used are $50 \%$ of the total accidents reports received from $H \& S$ team of the project. Out of 22 reports, nine incident reports were classified as property/equipment damage, one as AWI, two FAI, and five as LTI. A different set of questions were developed and applied to each incident. The model was validated by top management, including the HSE advisor, construction manager and 
project director of the construction organisation. All the valid incidents reports were reviewed against these questions and a conclusion was made on the main or root causes of each incident.

After reviewing the incident reports against the set of questions shown in Table 2, eight incidents were matched to one root cause. The remaining incidents (14 incidents) were having more than one main root cause (Table 5). In 2012, seven incidents completed reports were provided by the project HSE team. Two incidents matched to one root cause of 'worker' and another to 'management'. The remaining four incidents in 2012 had more than one root cause.

Table 5 Summary of accident classification and root causes of accidents investigated

\begin{tabular}{|c|c|c|c|}
\hline Year & Accident classification & Root cause & Total \\
\hline \multirow{7}{*}{2012} & Property/equipment damage & Environment + Management & \multirow{7}{*}{7} \\
\hline & AWI & Worker & \\
\hline & Property/equipment damage & Worker & \\
\hline & FAI & Environment + Management & \\
\hline & Property/equipment damage & Worker + Management & \\
\hline & Property/equipment damage & Management & \\
\hline & MTI & Equipment + Worker + Management & \\
\hline \multirow{8}{*}{2013} & Property/equipment damage & Worker + Environment & \multirow{8}{*}{8} \\
\hline & Property/equipment damage & Worker + Management & \\
\hline & MTI & Equipment + Worker + Management & \\
\hline & Property/equipment damage & Worker + Environment + Management & \\
\hline & LTI & Worker & \\
\hline & MTI & Worker + Management & \\
\hline & MTI & Worker + Management & \\
\hline & Property/equipment damage & Equipment/Material + Management & \\
\hline \multirow{2}{*}{2014} & LTI & Equipment/Material & \multirow{2}{*}{2} \\
\hline & LTI & Worker & \\
\hline \multirow{5}{*}{2015} & Property/equipment damage & Equipment/Material + Worker & \multirow{5}{*}{5} \\
\hline & FAI & Worker & \\
\hline & LTI & Worker & \\
\hline & MTI & $\begin{array}{l}\text { Equipment/Material + Worker + Environment }+ \\
\text { Management }\end{array}$ & \\
\hline & LTI & Worker + Management & \\
\hline Total & & & 22 \\
\hline
\end{tabular}

From eight valid accident reports of 2013, one incident was matched to 'worker' as a root cause while the remaining seven incidents had more than one root cause. In the year 2014, there were two valid accidents reports available. One incident had the root cause of 'material/equipment' and one incident to the root cause of 'worker'. The total valid 
accidents reports for the year 2015 were five out of which two incidents matched one root cause of 'worker', the remaining three incidents were having more than one cause as shown in Table 5.

Considering individual causes, for five incidents, 'equipment/material' was one of the root causes. For 17 incidents, 'worker' was one of the root causes of accidents. 'environment' was one of the root causes for five incidents; 'management' was one of the root causes for 13 incidents; and equipment/material was one of the root causes for six accidents.

\section{Conclusions}

The proposed model for identifying the root causes could be a useful tool for construction organisations in Oman to know the root causes of accidents on their projects. This will help them to develop strategies towards reducing the number accidents and thus reduce the cost associated with accidents. By using this model, construction organisations will be able to pinpoint the key areas which cause most of the accidents. The proposed model identifies the main causes of accidents in construction that arise from equipment/materials, workers, environment, and management. Although the model is used only on a road construction project, it can be adopted and can be used on other construction projects. This investigation has revealed that a significant proportion of accidents (41\%) arise from the 'worker'. Furthermore, it is found that Management factor contribution is $31 \%$, equipment/materials contribution is $14 \%$ and the environment contribution is $12 \%$. Different types of accidents are discussed and investigated in the research to identify their root causes. Understanding the main causes of construction accidents will aid construction organisations in directing their resources to high risk areas to improve their safety performance.

This work has described results of research where a model has been developed and applied to help identify the principal root causes of accidents on a major highway construction project in the Sultanate of Oman. The causes of accidents in construction will vary from project to project and from sector to sector in the construction industry. Exposure to the risk of construction hazards will also vary depending on whether the project is a new build or involves maintenance operations. The model developed in this study could be applied to accidents in other sectors including building, civil engineering, process plant construction, etc. It is essential that the model developed in this study is tested using accident data from other sectors in order to generalise the applicability of the model and the findings on the root causes of accidents in construction. Knowing the root causes of accidents in construction is one thing, however, further research need to be conducted how to eliminate all the causes of accidents in construction and how to achieve the goal of zero accident in construction projects.

\section{References}

Ali, A.S., Kamaruzzaman, S.N. and Sing, G.C. (2010) 'A study on causes of accident and prevention in Malaysian construction industry', Journal of Design + Built, Vol. 3, No. 1, pp.95-104.

Abdelhamid, T. and Everett, J. (2000) 'Identifying root causes of construction accidents', Journal of Construction Engineering Management, Vol. 126, No. 1, pp.52-60. 
Anderson, J. (1997) The Problems with Construction, The Safety and Health Practitioner, UK, 29 May, pp.29-30.

Booth, R.T. and Panopoulos, G.D. (2005) 'Economic aspects of safety in construction industry', 3rd Int. Conf. on Construction in the 21st Century(CITC-III): Advanced Engineering, Management and Technology, Dept. of Construction Engineering and Management, Faculty of Civil Engineering of the National Technical University of Athens, Athens, Greece, pp.15-17.

BRT (The Business Roundtable) (1995) Improving Construction Safety Performance Report A - 3, The Business Roundtable, New York, NY, USA.

Choudhry, R.M., Fang, D.P. and Mohamed, S. (2007) 'Developing a model of construction safety culture', Journal of Management in Engineering, Vol. 23, No. 4, pp.207-212.

Dubois, A. and Gadde, L. (2002) 'The construction industry as a loosely coupled system: implications for productivity and innovation', Construction Management and Economics, Vol. 20, No. 7, pp.621-631.

Gibb, A., Haslam, R., Gyi, D., Hide, S. and Duff, R. (2006) 'What causes accidents?', Proceedings of the Institution of Civil Engineers - Civil Engineering, Vol. 159, No. 6, pp.46-50.

Hamid, A.R.A., Majid, M.Z.A. and Singh, B. (2008) 'Causes of accident at construction sites', Malaysian Journal of Civil Engineering, Vol. 20, No. 2, pp.242-259.

Haslam, R.A., Hide, S.A., Gibb, A.G.F., Gyi, D.E., Pavitt, T., Atkinsonand, S. and Duff, A.R. (2005) 'Contributing factors in construction accidents', Applied Ergonomics, Vol. 36, No. 4, pp.401-415.

Hinze, J. (1996) 'The distraction theory of accident causation', in Alvez Diaz, L.M. and Coble, R.J. (Eds.): Proceedings of International Conference on Implementation of Safety and Health on Constr. Sites, CIB Working Commission W99: Safety and Health on Construction Sites, Balkema, Rotterdam, The Netherlands, pp.357-384.

Ikpe, E., Hammon, F. and Oloke, D. (2012) 'Cost-benefit analysis for accident prevention in construction projects', Journal of Construction Engineering Management, Vol. 138, No. 8, pp.991-998.

Kadefors, A. (1995) 'Institutions in building projects: implications for excitability and change', Scandinavian Journal of Management, Vol. 11, No. 4, pp.395-408.

Kadiri, Z.O., Nden, T., Avre, G.K., Oladipo, T.O., Edom, A., Samuel, P.O. and Ananso, G.N. (2014) 'Causes and effects of accidents on construction sites (a case study of some selected construction firms in Abuja F.C.T Nigeria)', Journal of Mechanical and Civil Engineering, Vol. 11, No. 5, pp.66-72.

Lehtola, M.M., Van Der Molen, H.F., Lappalainen, J., Hoonakker, P.L., Hsiao, H., Haslam, R.A., Hale, A.R. and Verbeek, J.H. (2008) 'The effectiveness of interventions for preventing injuries in the construction industry - a systematic review', American Journal of Preventive Medicine, Vol. 35, No. 1, pp.77-85.

Lubega, H., Kiggundu, B.M. and Tindiwensi, D. (2000), 'An investigation into the causes of accidents in the construction industry in Uganda', Proceedings of the 2nd International Conference on Construction in Developing Countries, 15-17 November, 2000, Botswana, pp.1-12.

McClay, R.E. (1989) 'Toward a more universal model of loss incident causation', Professional Safety, Vol. 34, No. 1, January, pp.15-20.

Mitropoulos, P., Abdelhamid, T.S. and Howell, A.G. (2005) 'Systems model of construction accident causation', Journal of Construction Engineering Management, Vol. 131, No. 7, pp.816-825.

NCSI (2015) Statistical Year Book, Issue 43, National Center for Statistic and Information, Muscat, Oman, See https://www.ncsi.gov.om/Elibrary/Pages/LibraryContentDetails.aspx? ItemID=lffQDcPJGNjEE5Xix4WK2g\%3d\%3d (Accessed 21 October, 2016). 
Suraji, A., Duff, A.R. and Peckitt, S.J. (2001) 'Development of causal model of construction accident causation', Journal of Construction Engineering Management, Vol. 127, No. 4, pp.337-344.

Tang, S.L., Ying, K.C., Chan, W.Y. and Chan, Y.L. (2004) 'Impact of social safety investments social costs of construction accidents', Journal of Construction Management and Economics, Vol. 22, No. 9, pp.937-946. 